Cahiers $d u$ MONDE RUSSE

\section{Cahiers du monde russe}

Russie - Empire russe - Union soviétique et États indépendants

42/2-4 | 2001

La police politique en Union soviétique, 1918-1953

\title{
Conflict and complicity : The expansion of the Karelian Gulag, 1923-1933.
}

\section{Nick BARON}

\section{OpenEdition}

\section{Journals}

Édition électronique

URL : https://journals.openedition.org/monderusse/8471

DOI : 10.4000/monderusse.8471

ISSN : $1777-5388$

\section{Éditeur}

Éditions de l'EHESS

\section{Édition imprimée}

Date de publication : 1 avril 2001

Pagination : 615-648

ISBN : 2-7132-1398-3

ISSN : $1252-6576$

Référence électronique

Nick BARON, "Conflict and complicity: The expansion of the Karelian Gulag, 1923-1933. », Cahiers du monde russe [En ligne], 42/2-4 | 2001, mis en ligne le 01 janvier 2007, consulté le 04 septembre 2022 URL : http://journals.openedition.org/monderusse/8471; DOI : https://doi.org/10.4000/monderusse. 8471 
chercher : repérer : avancer

Cet article est disponible en ligne à l'adresse :

http://www.cairn.info/article.php?ID REVUE=CMR\&ID NUMPUBLIE=CMR 422\&ID ARTICLE=CMR 4220615

Conflict and complicity: The expansion of the Karelian Gulag, 1923-1933

\author{
par Nick BARON
}

Editions de l'EHESS | Cahiers du monde russe

2001/2-3-4 - Vol 42

ISSN 1252-6576 | ISBN 2713213983 | pages 615 à 648

Pour citer cet article :

-BARON N., Conflict and complicity : The expansion of the Karelian Gulag, 1923-1933, Cahiers du monde russe 2001/ 2-3-4, Vol 42, p. 615-648.

Distribution électronique Cairn pour les Editions de l'EHESS.

(C) Editions de l'EHESS. Tous droits réservés pour tous pays.

La reproduction ou représentation de cet article, notamment par photocopie, n'est autorisée que dans les limites des conditions générales d'utilisation du site ou, le cas échéant, des conditions générales de la licence souscrite par votre établissement. Toute autre reproduction ou représentation, en tout ou partie, sous quelque forme et de quelque manière que ce soit, est interdite sauf accord préalable et écrit de l'éditeur, en dehors des cas prévus par la législation en vigueur en France. Il est précisé que son stockage dans une base de données est également interdit. 


\title{
CONFLICT AND COMPLICITY: THE EXPANSION OF THE KARELIAN GULAG, 1923-1933*
}

\begin{abstract}
1. Introduction
During the early morning of 8 February 1928, 21 year old Dmitrii Sergeevich Likhachev was arrested in his parents' flat on Oranienbaumskaia Street in Leningrad. After nearly a year in 'investigative detention' he was sent, together with student friends from a religious discussion group, to serve a five-year sentence in the prison camp on Solovetskii Island in the White Sea. Nearly sixty years later, interviewed during Gorbachev's glasnost' for a documentary film on the camp, Academician Likhachev recalled the words with which camp guards at the Kem' transfer point in central Karelia welcomed the newly arrived inmates descending from railway carriages: "There's no Soviet power here, only Solovetskii power!"1 This first encounter with the 'special' camp system ${ }^{2}$ evidently impressed itself deeply in his memory, for he recalled it also in his last published memoir:
\end{abstract}

* I am grateful to the UK Economic and Social Research Council for funding my research on Soviet Karelia in the 1920s and 1930s, which has formed the basis of this paper. I should also like to thank Bob Davies, Andrea Graziosi and Peter Gatrell for their comments on drafts of this work. Abbreviations of archives in references:

- Gosudarstvennyi Arkhiv Rossiiskoi Federatsii (GARF)

- Rossiiskii Gosudarstvennyi Arkhiv Sotsial'no-Politicheskoi Istorii (RGASPI, former Central Party Archive)

- Gosudarstvennyi Arkhiv Obshchestvenno-Politicheskikh Dvizhenii i Formirovanii Respubliki Kareliia (GAOPDF RK, former Karelian Party Archive).

- Tsentral'nyi Gosudarstvennyi Arkhiv Respubliki Kareliia (TsGARK)

- US State Department, Records relating to internal Soviet affairs, 1930-1939 (T1429).

- Manuscript Collection, Bakhmeteff Archive, Columbia University Library, New York.

1. From Marina Goldovskaia, Vlast' solovetskaia, Mosfil’m, 1989.

2. In this paper I use the term 'special' camp system to refer to the OGPU-NKVD network of prison camps, commonly known as the Gulag, as opposed to the camps and colonies at various times under the authority of the People's Commissariat of Justice or republican People's Commissariats of Internal Affairs. For the development of camp administrative structures and 
"I will not describe in detail the first days at Kem, on Popov island and in no. 13 company at Solovki ... there is no need to repeat everything. I will merely observe that as I got out of the car one of the escort drew blood from my face with his boot, and they all did their utmost to humiliate us. They shouted at us "Zdes' vlast' ne sovetskaia, zdes' vlast' solovetskaia."3

Officials of the Unified State Political Administration (the OGPU, informally known as the Chekists), who not only guarded the perimeters of camps, but also the external borders and internal social 'frontiers' of the state, cultivated the camp system in isolation from centres of formal political authority. Other Solovetskii memoir evidence also emphasises the Chekists' assertion of autonomy from central civil authority. ${ }^{4}$ One former prisoner described A. P. Nogtev, commandant of the Solovetskii camp, as "an absolutely abnormal person, a maniac, which does not prevent him from being the "tsar and god' over 5,000 prisoners." Although there is already a large and increasing body of secondary historiography on the Soviet Gulag 6 and a canon of memoir literature which offers insights into life and death in individual camps, there have been few attempts to investigate historically the structures and behaviour of the Gulag at regional level, or the politics of the Gulag between centre and periphery. ${ }^{7}$

their successive acronyms, see M. B. Smirnov, ed., Sistema ispravitel'no-trudovykh lagerei $v$ SSSR, 1923-1960. Spravochnik (Moscow: Zven’ia, 1998): especially pp. 103-106. For the development of prison jurisdictions, see Michael Jakobson, Origins of the Gulag. The Soviet prison camp system, 1917-1934 (Lexington: University Press of Kentucky, 1993).

3. Dmitry S. Likhachev, Reflections on the Russian soul. A memoir (Budapest and New York: CEU Press, 2000): 87.

4. See, among memoir sources on Solovetskii, D. S. Likhachev, Reflections on the Russian soul..., op. cit.; S. A. Malsagov, An island hell. A Soviet prison in the Far North (London: Philpot, 1926); J. D. Bessonov, My twenty-six prisons and my escape from Solovetsky (London: Jonathan Cape, 1929); Mikhail Rozanov, Solovetskii kontslager' v monastyre, 19221939 gg. Fakty. Domysly. "Parashi”. Obzor vospominanii solovchan solovchanami v dvukh tomakh (author's publication: 1979); Ivan Solonevich, Russia in chains (London: Unwin, 1938); International Committee for Political Prisoners, ed., Letters from Russian prisons (London: C. W. Daniel, 1925): 159-221. See also the memoirs of a timber administrator in Karelia who visited this camp, Karl Albrecht, Der verratene Sozialismus (Berlin and Leipzig: NibelungenVerlag, 1939); and also Alexander Solzhenitsyn, The Gulag archipelago, 1918-1956. An experiment in literary investigation. Part III (London: Collins/Harvill, 1975); and Ivan Chukhin, Kanaloarmeitsy: istoriia stroitel'stva Belomorkanala $v$ dokumentakh, tsifrakh, faktakh, fotografiiakh, svidetel'stvakh uchastnikov i ochevidtsev (Petrozavodsk: Kareliia, 1990).

5. Anonymous author, in Letters from Russian prisons, op. cit.: 170.

6. Among the most recently published works, see especially the handbook by M. B. Smirnov, ed., Sistema ispravitel'no-trudovykh lagerei $v$ SSSR ..., op. cit.; monographs by M. Jakobson, Origins of the Gulag..., op. cit.; and Galina Ivanova, Labor camp socialism. The Gulag in the Soviet totalitarian system (Armonk and New York: M. E. Sharpe, 2000); a collection of essays and photographs, Marcello Flores, Francesca Gori, eds, GULag. Il sistema dei lager in URSS (Milan: Mazzotta, 1999); and the dauntingly comprehensive literature survey by Ralf Stettner, Archipel GULag: Stalins Zwangslager - Terrorinstrument und Wirtschaftsgigant (Paderborn: Schöningh, 1996). See also the document collection A. I. Kokurin, N. V. Petrov, eds, GULAG (Glavnoe upravlenie lagerei), 1917-1960 (Moscow: Materik, 2000).

7. For a few recent examples of regional Gulag studies, see David J. Nordlander, "Origins of a Gulag capital: Magadan and Stalinist control in the early 1930s," Slavic Review, 57, 4 (Winter 1998): 791-812; James Harris, "The growth of the Gulag: forced labour in the Urals Region, 
The present paper attempts to explore these questions by addressing the development in the 1920s and early 1930s of 'special' institutions of forced labour in the Karelian Autonomous Soviet Socialist Republic (Karelian ASSR): the Solovetskii Camp of Special Designation (Solovetskii Lager' Osobogo Naznacheniia, SLON, 1923-1931) and the Belomorsko-Baltiiskii Canal construction and camp complex (Belomorstroi and Belbaltlag, 1931-1933). ${ }^{8}$ It draws primarily on recently released archival documents to substantiate and supplement the bare outline of the story already known from published memoir sources. I trace the subsequent history of the Belomorsko-Baltiiskii Kombinat (BBK, 1933-1941), from 1934 under the authority of the Soviet People's Commissariat of Internal Affairs (NKVD SSSR), in a sequel paper. ${ }^{9}$ Here, the central concern is to investigate the complex, evolving configurations of conflict and complicity among Soviet political, economic and security interests, both in the centre and locally, and the consequences of their policy decisions for both Karelia and the regional 'special' camp system. That I dedicate relatively little space to describing the prisoners themselves, their social origins, their struggles to survive and the remarkable resilience and achievements of many in the face of the most brutal repression, is not to depreciate the tragedy or dignity of their stories: the reader is urged to consult the many memoir and biographical sources on the Solovetskii camp. ${ }^{10}$

\section{The Solovetskii camp, 1923-1931: Exigencies, expediencies and expansion}

Soviet Karelia comprised the eastern section of the larger region of Karelia, which was divided from north to south in the fourteenth century, and remained divided between Russia in the east and Sweden (later, Finland) in the west. On gaining independence in 1918, Finland pressed for a revision of the state border with Soviet Russia to unite the two halves of Karelia within the new Finnish state. Partly to preempt such demands, partly to establish a model national territory for propaganda purposes, in 1920 Soviet Russia granted extensive economic and administrative

1929-1931," Russian Review, 56, 2 (April 1997): 265-280; Viktor Berdinskikh, Viatlag (Kirov: Kirovskaia oblastnaia tipografiia, 1998). It should be noted that the concept of 'periphery' has not only geographical, but also socio-cultural connotations. Of course, sociocultural and geographical space may coincide - many of the special camps were located in remote, peripheral regions of the country, and those situated in central areas were usually on the outskirts of big cities. For stimulating sociological perspectives on the 'periphery,' see among others, Edward Shils, Center and periphery. Essays in macrosociology (Chicago and London: University of Chicago Press, 1975): especially 3-16.

8. For details on these camps' administrations, see M. B. Smirnov, ed., Sistema ispravitel'notrudovykh lagerei $v$ SSSR..., op. cit., : 162-164, 394-397.

9. Nick Baron, "Production and terror: The operation of the Karelian Gulag, 1933-1939," to be published in the next issue of the Cahiers du Monde russe, 43, 1 (January-March 2002).

10. See footnote 4 . 
autonomy to eastern Karelia within the Soviet border. Edvard Gylling, an exiled Finnish social democrat, was appointed to lead the new territory, initially the Karelian Labour Commune (Karel'skaia Trudovaia Kommuna - KTK), from 1923 the Karelian ASSR. His desire to develop Soviet Karelia as a viable autonomous territory, which could act as a model of socialist inter-ethnic fraternity and mutual aid and as a beacon of revolution to the Finnish and Scandinavian working classes, dictated the imperative of building a strong, self-regulating and self-sufficient economy. However, local labour resources, further depleted by civil war population displacement, were sorely insufficient to implement his ambitious plans for post-war reconstruction, timber export and industrial development. In response, E. Gylling embarked on numerous projects to stimulate the resettlement of Karelians and Finns in the autonomous republic and to recruit a permanent workforce for its incipient industry.

In addition, the Karelian government during the first year of autonomy turned to the use of prison labour, in line with central penal labour policies and the increasing militarization of the Soviet economy..$^{11}$ This decision inevitably resulted in conflict with its rival regional authority. During 1920 and 1921, the administration of Olonets Guberniia (government, pre-revolutionary territorial unit), which before the creation of the KTK had exercised jurisdiction over the southern half of Russian Karelia, fought to retain authority over Petrozavodsk, capital at this time of both autonomous Karelia (where it was located) and of the residual territory of Olonets Guberniia which survived outside the borders of the Karelian commune. For a while, both authorities were reluctantly forced to share institutions, personnel and premises in the town. E. Gylling, however, was determined that Karelia should have full control over an integrated, contiguous and coherent territory, and over the resources contained within the borders of that space. One of the resources that E. Gylling now fought to wrest out of the hands of the Olonets administration was a kontsentratsionnyi lager' (concentration camp) located on the outskirts of Petrozavodsk. In June 1921, he submitted a petition to the NKVD of the Russian Republic (RSFSR) arguing for a transfer of the Neglinka saw-mill to the jurisdiction of the camp, and the camp itself to the authority of the Karelian Economic Council, since its "workforce can be used not only in the saw-mill but in other production, the development of which is delayed by lack of workforce to such an extent that it is impossible to fulfil even the most urgent tasks, for example, for export." Only if Karelia took over the concentration camp, E. Gylling asserted, would it be able "bravely and confidently to set to the task of fulfilling its economic programme." He concluded, indeed, that Karelia's special economic and administrative rights required the transfer, since the "principle of autonomy is irreconcilable with alternative authorities within an autonomous territory."12

11. On early Soviet penal labour policy, see M. Jakobson, Origins of the Gulag..., op. cit.: chapter 1. On war communism, see Alec Nove, An economic history of the USSR, 1917-1991 (London: Penguin, 1992): chapter 3.

12. GARF, f. 1318 (People's Commissariat of Nationalities, Narkomnats), op. 10, d. 6,1. 101. 


\subsection{The establishment of SLON, 1923}

"Somewhere at the end of the white world, on the shores
of the icebound sea, where eight months in the year
winter reigns, where for months the sun does not appear,
there stands the God-protected convent of Zosimo-
Savvatievo."
From a chronicle of the Solovetskii monastery, cited by an
anonymous prisoner, 1923.13

From the start, therefore, the Karelian authorities were ready to engage forced labour in the regional economy, so long as it furthered rather than compromised their spatial integrity and national autonomy. Consequently, it was with trepidation that they heard rumours in August 1923 that the OGPU was setting up a prison camp on the Island of the Revolution (formerly, Popov Island) in the bay of Kem' in central Karelia. This was worse than mere trespass, since Karelia had just won control over a saw-mill on the island and needed space there to accommodate a civil workforce, without the worrisome presence of either Chekists or their prisoners. ${ }^{14}$

In fact, a far greater threat to their autonomy was looming. In 1919 the OGPU's predecessor, the All-Russian Extraordinary Commission for Combatting CounterRevolution and Sabotage (VChK, or Cheka) had set up a number of forced labour camps to operate on their own resources in the Arkhangelsk region of northern European Russia (at Pertominsk, Kholmogory and near the regional capital itself). In 1921, this network became known as the Northern Camps of Special Designation (SLON). ${ }^{15}$ To facilitate the organisation of "efficiently productive work among the especially socially dangerous element," the camps had been freed from all taxes. ${ }^{16}$ In early 1923, the OGPU proposed massively to expand the northern system by establishing a new camp located on the Solovetskii archipelago, initially to house 8,000 prisoners, with a new transfer point on the Karelian mainland at Kem', which together with the existing Pertominskii camp and the Arkhangelsk transfer point (which at this time housed 1,200 prisoners) would form a new Solovetskii Forced Labour Camp of Special Designation (Solovetskii Lager' Prinuditel'nykh Rabot Osobogo Naznacheniia, SLON). According to the OGPU draft decree presented to the Russian Sovnarkom on 18 August 1923, this camp would hold "political and criminal prisoners sentenced by extra-judicial GPU organs, by the former VChK

13. In Letters from Russian prisons..., op. cit.: 162.

14. The saw-mill was transferred by decree of the Council of Labour and Defence (STO) on 30 May 1923. See letter from the Karelian Labour Commune (KTK) Executive Committee, signed by E. Gylling and Iushiev, to the Presidium of the All-Russian Central Executive Committee, dated 14 August 1923, in GARF, f. 5446, op. 5a, d. 1 ("On organisation of northern forced labour camps"), 1. 11.

15. M. Jakobson, Origins of the Gulag..., op. cit.: 39; see also "Explanatory notes" to second OGPU draft of decree "On the organisation of northern forced labour camps," dated 18 August 1923, GARF, f. 5446, op. 5a, d. 1,1.24.

16. GARF, f. 5446 , op. 5a, d. 1,1.24. 
and by the NKVD Special Board (Soveshchanie) for Administrative Exile" plus prisoners sentenced in regular courts if the GPU gave express permission. ${ }^{17}$ The Russian People's Commissariat of Justice (Narkomiust RSFSR) and the NKVD had already accepted an earlier draft, although the latter had demanded that a clear division of penal functions and funding should be established between institutions under its own Chief Prison Administration (Glavnoe Upravlenie Mest Zakliucheniia, GUMZ) and those under the OGPU.18 Inevitably, the Russian People's Commissariat of Finance (Narkomfin RSFSR) had expressed reservations about the plan, on the grounds that it required a substantial transfer of "property and productive value" to the OGPU and involved considerably increased central budgetary funding. ${ }^{19}$

At this moment, the Karelian authorities intervened to protest at what they thought was a new OGPU camp on the Island of the Revolution in Kem' bay. They claimed that it was impermissible "to flood with criminal elements parts of Karelia bordering on Finland [as it would] cause undoubted political harm and [would] paralyse all work of the economic organs to restore the region's economic life."20 In a petition to the NKVD dated 1 August 1923, the People's Commissar of Internal Affairs of the Karelian ASSR, N. V. Arkhipov, complained that because criminals on the island were poorly guarded they frequently escaped into the thick mainland forests and spread fear and mayhem among the local population..$^{21}$ In reply, Head of the Administration of the Northern Camps (USLAG) A. P. Nogtev pointed out that Karelia only controlled the saw-mill on the island, while the territory itself and its timber resources belonged to the People's Commissariat of Transport (Narkomput ${ }^{\text {) }}$. This administration had therefore acted within its rights when it agreed to transfer several empty barracks to USLAG to serve not as a separate camp, he emphasised, but as a transit point between the Kem' railway station and the new camp on Solovetskii Island (which was, in fact, located within the maritime borders of the Northern krai, later Arkhangelsk Region, or oblast', not within Karelian territorial jurisdiction). ${ }^{22}$ Ignoring Karelian protests, Sovnarkom on 2 October 1923 issued a decree establishing the new Solovetskii camp with two transit points at Arkhangelsk and $\mathrm{Kem}^{\prime}$, and transferring to it all the goods,

17. Second OGPU draft of decree "On the organisation of northern forced labour camps," dated 18 August 1923, GARF, f. 5446, op. 5a, d. 1,1.2.

18. Letter of A. G. Beloborodov (GUMZ) to Unshlikht (GPU), dated 14 June 1923, GARF, f. 5446, op. 5a, d. 1, 11. 3-6.

19. At that date, central funding was limited to only a small number of penal institutions, housing in total fewer than 15,000 prisoners sentenced by civil organs and 17,300 prisoners sentenced by the GPU. See letter from Budgetary Administration of Narkomfin to GPU, dated 17 June 1923, GARF, f. 5446, op. 5a, d. 1,1.9.

20. GARF, f. 5446, op. 5a, d. 1,1.11.

21. Letter from Regional Administrative Department of the Karelian Labour Commune, signed by N. V. Arkhipov, to the NKVD, dated 1 August 1922 [sic, probably 1923], in GARF, f. 5446, op. 5a, d. 1,1.21.

22. Letter from A. P. Nogtev to the Executive Committee of Arkhangelsk oblast', dated 19 July 1923 , in GARF, f. 5446, op. 5a, d. 1, 1. 15. 
buildings and "living and dead" inventory of the former Solovetskii monastery, the Pertominskii camp (which was subsequently closed) and the Arkhangelsk camp. The OGPU was instructed immediately to organise work for the prisoners in agriculture, fishing, timber and other enterprises. The camp was to be selfsufficient, and was freed from state and local taxes..$^{23}$ The first contingents of prisoners had already sailed from Arkhangelsk to Solovetskii in July. ${ }^{24}$

The Karelian authorities, having sent petitions against the Solovetskii camp to the Head of the OGPU F. E. Dzerzhinskii, to the Council of Labour and Defence (STO), to the All-Russian Central Executive Committee (VTsIK) and to the NKVD, but to no avail, were understandably dissatisfied with this decision. On 21 December 1923, the Presidium of the Karelian Regional Party Committee (Obkom) heard a report that prisoners in the "concentration camp" on the Island of the Revolution enjoyed "extreme freedom" (sic), some even travelling at will to Moscow, and resolved to petition the Party Central Committee (TsK) on the "abnormal situation" in the "forced labour camp" in Kem'. 25 A few months later, the First Obkom Secretary J. E. Järvisalo wrote to Moscow to reiterate the regional protest. ${ }^{26}$ When navigation between the mainland and Solovetskii Island had closed the previous year, he claimed, over one thousand prisoners were stranded on the Island of the Revolution, and Karelia had been unable to find space to house its own workers for the saw-mill. Moreover, in the absence of a sufficient guard, prisoners could freely make the brief crossing from the transit camp to the mainland. From $\mathrm{Kem}^{\prime}$, some were escaping westwards, where they were making contact with Finnish agents, he inferred, since reports of the Solovetskii camp were already being published in Finnish newspapers. Other prisoners were handing themselves in to the Kem' militia, since the town's prison was considerably more comfortable than the OGPU barracks.

\subsection{The expansion of SLON, 1923-1929}

The centre paid no heed to Karelia's vigorous protests. The SLON transit point remained on the Island of the Revolution, and the Solovetskii camp itself continued to grow and expand its economic activities. However, the camp's productive output and trading activities were insufficient to enable it to achieve self-sufficiency. During the following years, the Solovetskii camp inexorably expanded in pursuit of this objective.

23. Decree in GARF, f. 5446, op. 5a,d.1,1. 1 .

24. See the account in Letters from Russian prisons..., op. cit.: 165.

25. GAOPDF RK, f. 3, op. 1, d. 216,1.182ob.

26. Letter to TsK dated 11 March 1923, "On location of transit point for Solovki concentration camp on the Island of the Revolution, Kem' uezd, Karelian Republic," in RGASPI, f. 17 (Central Committee), op. 33 (Secret Department), d. 218, 11. 84-86. 
During the 1924/1925 financial year, the SLON Administration (USLON) received a subsidy of 500,000 rubles from the government towards the cost of its 3,500 prisoners (equivalent to a subsidy of 143 rubles per head). ${ }^{27}$ In March 1925, OGPU Collegium member G. G. Iagoda, together with the Head of the OGPU Special Department (responsible for the camps at this time) G. I. Bokii and OGPU's Head of Finance L. I. Berenzon (later Head of Finance for Belomorstroi), submitted a request to the Union Sovnarkom's Administrative-Financial Commission for a further subsidy of 600,000 rubles to cover USLON's deficit for the following financial year (starting in June). They justified this appeal by noting that in 1925/ 1926 they planned to maintain 5,000 prisoners in the Solovetskii camp at a reduced cost to the state's reserve funds of 110 rubles per prisoner, whereas civil prisons the previous year had cost the budget 201 rubles for each inmate. ${ }^{28}$ For the sake of comparison, it should be noted that the average annual wage in the civilian economy in 1925/1926 was 571 rubles. ${ }^{29}$ The Commission sent the OGPU's request to the Military and Naval Department of the Narkomfin Budgetary Administration for comment. The latter advised that USLON's expenditures should be covered wholly by the OGPU's own budget, and observed that the agency was only demanding subsidies because it had "artificially" inflated its costs. ${ }^{30}$ Nevertheless, the Sovnarkom Commission, after meeting to hear reports from L. I. Berenzon, A. P. Nogtev (now head of USLON) and Narkomfin official Shaturin (no first names identified), agreed in a secret protocol to grant the desired 600,000 rubles for the second half of 1925 . A session of the STO chaired by L. V. Kamenev confirmed this decision on 15 April 1925. ${ }^{31}$

Such requests became an annual item on the agendas of central administrations responsible for extra-budgetary funding. In May 1926, the Finance Department of the OGPU requested 1,200,000 rubles to cover USLON's envisaged deficit for the forthcoming financial year, calculated on a projected average of 10,000 prisoners. This year, they noted, the state would only pay 153 rubles towards the maintenance of prisoners in the Solovetskii camp (whereas prisoners in civil institutions cost 220 rubles). Not only were OGPU prisoners cheaper, they could also be recruited more easily and worked harder: "After careful consideration of our estimates, and with regard for the difficult situation of the state budget," continued the appeal, "[we] have recognised the possibility of expanding the camp's productive enterprises

27. Letter from G. G. Iagoda, G. I. Bokii and L. I. Berenzon to Union Sovnarkom's Administrative-Financial Commission, dated 25 March 1925, in GARF, f. 5446, op. 5a, d. 720, 1.2.

28. Ibid.

29. According to Trud v SSSR, 16-17 (1936). I am very grateful to Bob Davies for indicating this source to me.

30. Letter to Sovnarkom SSSR Administrative-Financial Commission, dated 30 March 1925, in GARF, f. 5446, op. 5a, d. 720,1.3.

31. Protocol 168 of Sovnarkom SSSR Administrative-Financial Commission, dated 8 April 1925, in GARF, f. 5446, op. 5a, d. 720,11. 4, 5; Secret supplement to protocol 170, dated 8 April 1925, in ibid.,1. 6; Protocol 144-6 of STO, in ibid.,1.7. 
above the limits envisaged in the plan." By increasing output, USLON could raise its income from the current projected level of 1,700,000 rubles by 350,000 rubles. However, to do this would require a substantial initial investment in technology.32 The response from Narkomfin SSSR was severe: the economists considered that USLON could cut 270,000 rubles from its expenditures by reducing the cost of purchasing food, clothing, medical and other supplies ${ }^{33}$ Seeking a compromise, the OGPU lowered its request to $1,060,000$ rubles, which was accepted by the STO in July. It was also agreed that the OGPU would cover 500,000 rubles of this sum from its current inventory of confiscated property and money, with the remainder taken 'on credit' from the Sovnarkom 1925/1926 reserve fund (which would deduct an equivalent amount from future sales by the OGPU of confiscated property). ${ }^{34}$

In a further communication a few months later, Narkomfin berated USLON for increasing its camp population from 5,000 to 10,000 within the course of only one year. This excessively rapid growth, the economists noted, had "rendered the principle of self-sufficiency (samookupaemost') of the camps less viable." ${ }^{\prime 35}$ The OGPU evidently believed to the contrary that expanding USLON's productive population would in time enable the camp to achieve economic autonomy. Indeed, G. G. Iagoda claimed that USLON had only been forced into deficit because in late 1925 it had established a Colony for the Malicious Poor (Koloniia dlia zlostnykh nishchikh) to accommodate a large contingent of beggars, who had been expelled from Moscow as "social parasites" and among whom there were a disproportionate number of "cripples." 36

Certainly, the Solovetskii camp continued to grow in population and to increase both sides of its balance sheet, although not proportionately. According to OGPU figures, USLON expanded in $1927 / 1928$ to 13,323 prisoners and received $1,589,000$ rubles from the state budget (equivalent to 120 rubles per prisoner) ${ }^{37} \mathrm{As}$ of May 1928, USLON envisaged an increase in population during the following financial year to 17,000 prisoners and a corresponding increase in its deficit to $2,100,000$ rubles. However, Narkomfin as usual raised objections and G. G. Iagoda agreed that USLON could make do with a subsidy of 1,600,000 rubles by lowering expenditure per prisoner to a mere 94 rubles (in contrast to 240 rubles in civil prisons), and by raising higher revenues from expanded contractual operations on

32. Letter to Sovnarkom SSSR, dated 29 May 1926, in GARF, f. 5446, op. 7a, d. 537, 11. 1-6.

33. Letter of Narkomfin SSSR to Sovnarkom SSSR, dated 11 June 1926, in GARF, f. 5446, op. 7a, d. $537,1.7$.

34. Letter of OGPU to Sovnarkom SSSR, dated 3 July 1926, in GARF, f. 5446, op. 7a, d. 537, 1. 7; Resolution of STO, dated 28 July 1926, in ibid.,1. 24.

35. Letter of Narkomfin SSSR Budgetary Administration of the Army and Navy Department, dated 23 October 1926, in GARF, f. 5446, op. 7a, d. 113,1.2.

36. Letter from the OGPU Financial Department, signed G. G. Iagoda, to Sovnarkom SSSR, dated 30 September 1926, in GARF, f. 5446, op. 7a, d. 113,1.1.

37. Letter from the OGPU, signed by G. G. Iagoda, to Sovnarkom SSSR, dated 7 May 1928, in GARF, f. 5446, op. 9a, d. 444,1.2. 
the Karelian mainland (since the camp had already achieved capacity output on the islands). ${ }^{38}$ In joint session, the STO and Sovnarkom agreed to this sum, offering one million rubles from the SNK reserve fund and deducting the remainder from future OGPU earnings. ${ }^{39}$

In this way, the OGPU steadily expanded the USLON camp population and its use of prisoners' forced labour with the aim of increasing revenues and reducing its stubbornly persistent dependence upon funding from central government. However, the total costs incurred by the camp's disproportionately rapid expansion and increasingly complex economy each year exceeded the new levels of income, forcing the camp to seek even greater inputs from the centre, in the form of both higher subsidies and new supplies of labour. An additional and not incidental consequence of these developments was the incremental reduction of expenditure per prisoner and corresponding debasement of living conditions. As early as October 1924, Deputy Head of the OGPU V. R. Menzhinskii wrote to the STO requesting sufficient strong spirit for prisoners working in lumbering and fishing enterprises in harsh climatic conditions. ${ }^{40}$ The "minimum" ration required presumably meaning to prevent death by freezing in the sub-Arctic Solovetskii winter - was just over one millilitre of $96^{\circ}$ spirit per convict per day. There is as yet no systematic statistical evidence of living standards in the 1920 s, but for abundant and horrifying testimony of the heavy human and spiritual cost of such brutally banal calculations, we need only turn to the abundant memoir literature on the Solovetskii camp. ${ }^{41}$

\subsection{Relations between USLON and the Karelian authorities, 1923-1929}

Having fought bitterly but unsuccessfully in 1923 to prevent the OGPU from establishing the Solovetskii prison camp, the Karelian leadership throughout the mid-1920s strove to resist the expanding employment of SLON forced labour on Karelian territory. However, the Murmansk Railway timber administration (Zhelles), to which the STO had transferred large swathes of central and northern Karelian forest in May 1923, willingly accepted the supply of SLON contract labour to fulfil its own separate production and export plans. ${ }^{42}$ In an attempt to halt this practice, the Karelian Central Executive Committee (TsIK) passed a resolution in early 1925 forbidding the employment of Solovetskii camp prisoners inside the republic. When the OGPU protested against this resolution to the Union TsIK in

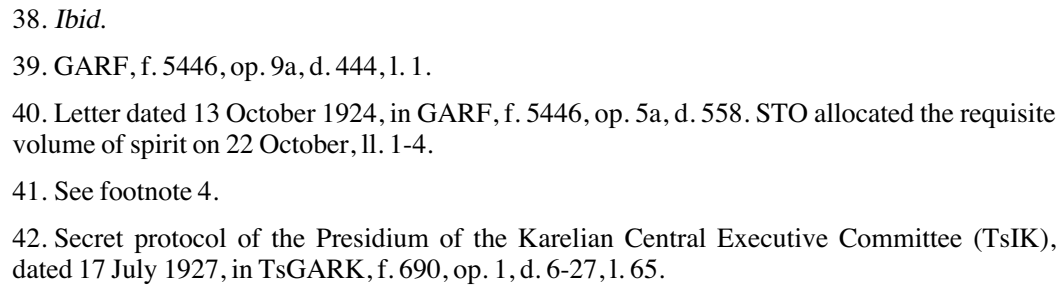


Moscow, E. Gylling hurried to submit a statement to this body's Presidium (of which he was a member) defending the autonomous republic's prerogative to regulate the use of labour within its own borders, regardless of the immediate territorial or productive jurisdiction within which the workforce operated. The Presidium of the Union TsIK, caught between loyalty to its own member and the impulse to uphold his civic authority on the one hand, and the daunting 'special' powers of the OGPU on the other, resolved on a compromise in April 1925, whereby they warily "proposed to the OGPU that in future it should first agree questions of using its concentration camp [sic] workforce within Karelian borders with the TsIK of the Karelian SSR [sic]."43

Neither Karelia nor the OGPU could be satisfied with this ambiguous directive, which hardly promised to resolve the continuing conflict between the two authorities. When the Northern Timber Organisation Severoles contracted a contingent of SLON prisoners for felling within Karelian territory in late summer of the same year without first obtaining permission from the republican government, the Karelian Obkom established a committee, chaired by E. Gylling and comprising two Karelian representatives plus delegates from Narkomput', Severoles and USLON, to reach a definitive settlement of this question. ${ }^{44}$ When agreement proved impossible, E. Gylling issued a terse reprimand to the administration of Severoles and set off to USLON headquarters on Solovetskii Island to negotiate a deal. However, pragmatism overtook his purpose. On 31 August 1925, the Presidium of the Obkom passed a resolution conceding that the northern Karelian workforce was not sufficient to fulfil local felling plans for 1925/ 1926, so USLON should be granted temporary timber felling quotas in these districts. In return for permission to use forced labour, Severoles should supply the local civil population with food and alternative felling work (in other words, not in the vicinity of prisoners). ${ }^{45}$ The Karelians also decided that although USLON labour could be used on the construction of the Kem'-Uhkta highway, the entire project should not be transferred to USLON but should remain under Karelian administration. At the same time, the regional party submitted the first of many petitions to the centre for the transfer of the Solovetskii islands to Karelian territory, and the latest of many requests to move the OGPU transit point off the Island of the Revolution - none of these appeals was granted. In the meantime, Zhelles simply continued to ignore the ban on Solovetskii labour. ${ }^{46}$

43. Protocol 52 of the Presidium of the SSSR Central Executive Committee (TsIK), dated 24 April 1925, in GARF, f. 3316, op. 16a, d. 178,1.17.

44. Protocol of Presidium of Karelian Obkom, dated 11 August 1925, in GAOPDF RK, f. 3, op. 1, d. $585,1.105$.

45. Protocol of Presidium of Karelian Obkom, dated 31 August 1925, in GAOPDF RK, f. 3, op. 1, d. $585,1.114$.

46. A representative of the Murmansk railway admitted to the Presidium of Karelian TsIK in July 1927 that his administration had contracts for USLON labour in force until October, but promised not to renew them after that date. E. Gylling acerbically reminded him that the use of USLON labour had been banned two years previously. See Secret Protocol of Presidium of Karelian TsIK, dated on 17 July 1927, in TsGARK, f. 690, op. 1, d. 6-27,1. 65. 
Karelia's production targets, especially for timber felling, increased sharply in the late 1920s as its economy was brought under the control of central planning authorities. However, neither central resettlement initiatives nor the republican government's colonisation and recruitment strategies, designed to boost the region's ethnic Finnish and Karelian population, succeeded in sufficiently augmenting the local population or attracting seasonal workers to the region. On the other hand, the Solovetskii camp offered a local, readily available and growing reserve of labour. Increased local demand was conveniently met with expanding USLON supply, itself a result of economic imperatives within the camp system, as we have seen above. Almost every year until the end of the decade, the Karelian authorities grudgingly issued emergency governmental or party decrees permitting local economic agencies to hire contingents of OGPU prisoners for felling or specific construction projects. Incrementally, therefore, the camp extended its hinterland sphere of operations on the mainland outwards from Kem' on the coast as far north as Murmansk (after 1928, part of Leningrad oblast') and into the south and east of the autonomous republic.

Naturally, the republican authorities lamented this development and its consequences as much as they relied upon it. At a meeting of the Karelian Obkom Bureau in June 1928, the head of the Karelian State Political Administration (the political police, GPU), who reported to the Moscow OGPU centre independently of the 'special' camp authorities, noted that 176 SLON prisoners had escaped on the mainland during 1927 and the first half of 1928, often in groups which roamed the countryside terrorising local populations. Another local official voiced his concern about the increased incidence of murder and rape in the vicinity of forced labour operations. J. E. Järvisalo replied that he had protested in the centre against SLON's growing encroachment onto the mainland, but had been informed that Solovetskii Island was now too small to accommodate the entire camp population (this, of course, was untrue: in fact, the archipelago had adequate space, but insufficient resources or productive potential to meet the camp's self-sufficiency targets). Nevertheless, the Obkom Bureau passed a resolution stating, with a hint of despairing resignation, that if the Karelian timber organisation (Karelles) had "the slightest possibility of not using prisoners for its felling workforce, then it should not." Nor should the Murmansk railway use OGPU contingents if it could manage without; the only project that absolutely required prison labour was the Kem' to Ukhta highway construction, and the number and quality of guards along that tract should be strengthened ${ }^{47}$

During the First Five-Year Plan, the Karelian authorities finally gave up resisting the encroachment by USLON onto mainland territory. The total collapse of the free labour supply as a result of collectivisation and increased competition for workers among regions, sectors and enterprises, together with miserable levels of local kolkhoz mobilisation - despite the attempt to introduce obligatory felling and road-building service (corvée) - necessitated increasing recourse to the

47. GAOPDF RK, f. 3, op. 2, d. 236,1.67. 
employment on contract of OGPU forced labour. In any case, the centralisation of economic decision-making, budgetary control and labour resource allocation during 1929/1930 rendered Karelia's special autonomous rights increasingly meaningless in practice, even if they survived in principle. Moscow commissariats and agencies had few compunctions about compromising the territorial and national integrity of the autonomous republic by encouraging the import of a huge non-national convict population, and they continued to ignore Karelian protests concerning the strategic and political dangers of locating large numbers of prisoners close to the border zone, as well as complaints about criminality and disorder in central districts (raiony) and the dangers of mixing free and prison workforces. ${ }^{48}$

\subsection{The origins of the Gulag empire, 1929-1931}

Russia had long traditions of political and religious deportation and convict transportation, sometimes combined with forced labour (katorga, first introduced as a penal measure in the late 1600s). The motives behind sustaining this policy were complex. In the words of a Russian jurist of the late nineteenth century,

"Russia, in fact, has never considered [transportation] merely as a punishment, but has used it as a means to resolve problems of internal and external politics [...] it is one of those rare creations of Russian penal law, born entirely of the needs and conditions of Russian life." 49

After the Revolution, there was renewed interest in penal transportation as a means to meet, in the first instance, the political exigencies of the embattled revolutionary regime. As we have seen, as early as 1919 the Soviets had established concentration camps in Arkhangelsk oblast' to isolate antagonistic groups and nefarious individuals extracted from the centre. Since the early 1920s, however, certain interests had also considered reviving the use of penal resettlement as a means to colonise remote regions and to exploit their resources (penal exile having been

48. For example, in a report to the Information Department of the OGPU Administration of the Leningrad Military Okrug of 10 February 1929, the head of the Karelian GPU Nel'ke noted that the Karelles saw-mill No. 40 in Kem' (on the Island of the Revolution) in 1927-1928 employed 698 permanent free workers and 347 USLON prisoners. Because the free workers were politically reliable, claimed Nel'ke, the prisoners' attempts to spread anti-Soviet and antisemitic agitation failed, but their presence did cause resentment among the free workers who feared they would be replaced with forced labour, and who saw that the prisoners received better supplies through corruption at USLON than they did through civil channels. This report evidently emphasises both central policy priorities of the time and Karelian preoccupations, and exemplifies the problems of using such sources. GAOPDF RK, f. 3, op. 2, d. 80-365, 11. 2237.

49. Ivan Foinitski in I. Foinitski and Georges Bonet-Maury, La transportation russe et anglaise avec une étude historique sur la transportation (Paris: Lecène, Oudin et Co., 1895): 150. I. Foinitskii opposed transportation, although he conceded that "elle a eu ses défenseurs comme peine, comme mesure de sûreté à l'intérieur ou comme moyen d'expansion coloniale," in ibid.: 257. 
abolished by the tsarist regime in 1900). Head of the OGPU Dzherzhinskii wrote in 1923:
"The republic cannot be merciful towards criminals and cannot waste resources on them; they must cover the costs associated with their care with their own labor; they must be used to settle undeveloped areas in Pechora, in Obdorsk (Salekhard) [...] We will have to work to organise forced labour (penal servi- tude) at camps for colonising undeveloped areas that will be run with iron disci- pline. We have sufficient locations and space." 50

The idea that forced labour could offer both self-sufficiency on the periphery and potential economic gain for the centre also appealed to economic interests. In November 1925, Deputy Chairman of the Supreme Council of the National Economy of the SSSR (VSNKh) G. L. Piatakov sent a report to his superior, who also happened to be Dzherzhinskii (in his role as the Chairman of VSNKh). The memorandum stated:

"My study of geographical factors affecting industrial issues has convinced me that in order to create the most elementary conditions for a work culture, compulsory labor settlements will have to be established in certain regions. Such settlements could also relieve overcrowding in places of incarceration. The GPU should be instructed to explore these issues." 51

In the late 1920s, as it became evident that ambitious Soviet schemes, initiated both centrally and locally, to promote the voluntary settlement of remote regions of the North had failed, the OGPU undertook to assume the leading role in resettlement. In 1929, G. G. Iagoda proposed a programme for the penal colonisation of vast territorial expanses, initially in Ukhta and Pechora, but ultimately stretching from Karelia and the Kola peninsula, where USLON was already actively expanding, to the Far East. The immediate objective of this strategy, as stated in the Politbiuro decree 'On the use of the labour of criminal prisoners' of 27 June 1929, was to "colonise these areas and exploit their natural resources by means of the use of prisoner labour." 52

OGPU's experience of running the Solovetskii camp had demonstrated at least two things. Firstly, the centre was willing to subsidise the continuous expansion of forced labour and thereby to underwrite the increased involvement of the OGPU in the economy. Secondly, the agency's growing economic significance further enhanced its prestige and power in the centre and boosted its ability to secure higher inputs in capital and labour investment to compensate for its higher costs. The OGPU, for example, was able to secure a decision, despite the opposition of

50. "F. E. Dzerzhinksii o revoliutsionnoi zakonnosti," Istoricheskii arkhiv, 1 (1958): 19, 21, cited in G. Ivanova, Labor camp socialism..., op. cit.: 186.

51. G. L. Piatakov had in mind, in the first instance, the northern reaches of the Enisei river, Sakhalin, the Kirgiz steppe and the Nerchinsk district. Cited in G. Ivanova, Labor camp socialism..., op. cit.: 70 .

52. Politbiuro resolution of 27 June 1929, in RGASPI, f. 17, op. 3, d. 746, 1. 11 
Narkomiust and the republican interior ministries, that all prisoners sentenced to over three years were to be transferred to its jurisdiction and employed in the 'special' camps, so long as they were suited to physical labour. ${ }^{33}$

In the longer term, G. G. Iagoda envisaged that this expanded network of corrective labour camps (Ispravitel'no-Trudovye Lageria, ITL, as concentration camps would henceforth be known) would develop into settlements of free workers populating and assimilating the vast empty northern territories. ${ }^{54}$ To encourage settlement, prisoners demonstrating exemplary work or behaviour could look forward to pre-term release from captivity, on condition they remain in these inhospitable areas. Other prisoners who had served their full terms but had been deprived of the right to free choice of residence, as well as those who volunteered to remain, would benefit from allocations of land in these peripheral regions and cash grants or equipment. In addition to these measures, the republican interior ministries were directed by the same decree to ensure all prisoners judicially sentenced to terms of between one and three years should be organised for optimal productive output into special agricultural and industrial colonies and to reduce to a minimum the number of institutions of incarceration..$^{55}$

The Karelian Obkom Bureau saw both opportunities and dangers in this policy. Among the perceived benefits were the increased regional capital investment that a powerful agency in the centre could secure, a steady supply of labour for felling and construction enterprises and, in the longer term, a means of colonising the remote northern areas of the autonomous republic. In the late summer of 1929, the Karelian party passed a resolution acknowledging that it was necessary to ensure "the maximum use of the USLON workforce on Karelian territory," especially in felling, and to use prisoners to establish agricultural and stock rearing kholkhozy in the exiguously populated northern districts. The USLON party organisation was directed to conclude a contract with Karelles to supply sufficient labour to achieve a doubling of the republic's felling output. For this purpose, the Karelian Obkom also directed the republican government to draw up a plan to transfer several forest areas directly to USLON jurisdiction. ${ }^{56}$

Increasingly desperate for labour resources, the Karelian authorities also directed the GPU to enforce the corvée more harshly, introduced severe penalties for 'desertion' from felling duties and increased the use of 'forced labour without

53. Politbiuro resolutions of 16 May and 27 June 1929 'On the use of the labour of criminal prisoners,' RGASPI, f. 17, op. 3, d. 740,1. 6 and d. 746,1. 11.

54. Politbiuro resolution of 27 June 1929 'On the use of the labour of criminal prisoners,' RGASPI, f. 17,op. 3, d. 746,1.11.

55. RGASPI, f. 17, op. 3, d. 746, 1. 11. See also Sovnarkom SSSR decree 'On the use of the labour of criminal prisoners,' 11 July 1929, reprinted in M. I. Khlusov, ed., Ekonomika GULAGa i ee rol' v razvitii strany. 1930-e gody. Sbornik dokumentov (Moscow: Institute of Russian History, Russian Academy of Sciences, 1998): 19-20.

56. Protocol of Karelian Obkom Bureau, dated 28 September 1929, in GAOPDF RK, f. 3, op. 2 , d. 329, 1. 57. 
deprivation of liberty. ${ }^{57}$ They also turned to the civil penal agencies. In November 1929, the Karelian Obkom permitted Karelles to sign a contract with GUMZ for the employment of its prison labour in felling, and directed the party fraction in the republican government to help organise NKVD prison colonies..$^{58}$ In May 1930, the Karelian Obkom resolved temporarily to increase the number of GUMZ prisoners in Karelia from five to six thousand: their extra labour was to be employed on road construction, recently decreed a priority for strategic reasons. It also directed the Karelian Sovnarkom to discuss transferring administration of GUMZ prison colonies on its territory from the Russian federal authorities to the Karelian NKVD. Finally, the Karelian party undertook, in line with the Politbiuro and SNK decrees of June 1929, to despatch all local GUMZ prisoners with terms of over three years to USLON. . $^{59}$

At the same time as permitting this massive increase in Gulag activity on their territory, the Karelian leadership attempted to curb local Chekist independence and ensure co-ordination of activity between civil and camp authorities. In March 1929, the Karelian party requested the TsK to subordinate the Solovetskii party collective to the Karelian Obkom and to establish an USLON party committee to rank alongside Karelian raion party committees (raikomy) ${ }^{60}$ The Karelians argued that three factors necessitated this measure. Firstly, the camps were geographically dispersed among Karelia, the Northern krai and Murmansk okrug without any unified party leadership. Secondly, the dispersal of OGPU party members among different districts (twenty in Kandalaksha raion, fifteen in Soroka, thirty in Medvezh' ia Gora in Karelia, and fifty on Solovetskii Island in Arkhangelsk oblast') undermined the centralised administration of the camps in Kem' (where there were one hundred Chekist party members) - with this, the Karelians were evidently seeking to establish under their control a unified party leadership in the camp system as a rival to the existing unified OGPU camp leadership. Thirdly, as a result of the lack of clarity concerning the role of district party committees in relation to the camps located within their territorial jurisdiction, "abnormal relations" had developed between raion leaderships and local camp administrations. ${ }^{61}$

However, the TsK Organisational-Distribution Department refused either to establish an USLON party committee or to subordinate the scattered Chekist party

57. For a general description of party and security measures to mobilise the rural workforce to felling, see F. Pottoev, “Sovetskoe stroitel'stvo AKSSR," in G. S. Rovio, N. A. Iushchev, E. A. Gylling, et al., eds, Sovetskaia Kareliia. Ocherki partiinogo, sovetskogo i kul'turnogo stroitel'stva AKSSR (Moscow and Leningrad: OGIZ, 1933): 120-146.

58. Karelian Obkom Bureau, 18 November 1929, GAOPDF RK, f. 3, op. 2, d. 331, 1. 54.

59. Karelian Obkom Secretariat, 20 May 1930, GAOPDF RK, f. 2, op. 2, d. 434, 11. 72-73.

60. The appeal to the TsK of 28 March 1929 is cited in a letter of OrgRasPred TsK to Karelian Obkom, Leningrad Obkom and Severnyi krai Obkom, dated 18 June 1929, in RGASPI, f. 17, op. 33, d. 437, 1. 71. The Karelians lodged a second appeal on 28 August, see Memo to Secretariat TsK, no date (soon after 28 August, 1929), RGASPI, f. 17, op. 33, d. 437, 11. 80, 98, and requested Leningrad's support for this petition in September, see Protocol of Karelian Obkom Bureau, 28 September 1929, GAOPDF RK, f. 3, op. 2, d. 329, 1. 57.

61. As summarised by the TsK's rapporteur, in RGASPI, f. 17, op. 33, d. 437, 11. 80, 98. 
collectives to the Karelian Obkom. Firstly, they argued, the transfer of the USLON headquarters to Kem' in August 1929 meant that the camp system would be concentrated predominantly within Karelia. Secondly, the proposed measure would do nothing to improve the relationship of the dispersed cells of OGPU party members to the central USLON leadership (thus the TsK defended the Chekist line of command from party intervention). Thirdly, the Karelian Obkom could improve relations between raion officials and local camp administrations by improving its leadership of the district committees. ${ }^{62}$ As a concession to Karelia, the TsK Organisational Bureau (Orgbiuro) in June had proposed that, once the Karelians had secured the approval of the VTsIK Administrative-Territorial Commission and the OGPU, they could submit another petition to the Presidium of VTsIK requesting the transfer of the Solovetskii islands to Karelian territory ${ }^{63}$

Minor adjustments of the administrative map were, in fact, by now irrelevant. With a view to implementing G. G. Iagoda's ambitious schemes for OGPU expansion and ensuring that the Solovetskii camp consolidated its position as the centre of productive forced labour activities in the North, A. P. Nogtev presented the OGPU centre in April 1930 with a plan for the comprehensive restructuring of the regional camp system, in accordance with the new 'Statute on ITL' published at the beginning of the month. ${ }^{64}$ This plan envisaged a streamlined central administration organised according to productive branches and an extensive territorial network of twelve self-supporting camp sections, each with subdepartments of the central branch administrations, across the Karelian and Kola mainland. The project was designed specifically to maximise the productive efficiency of forced labour organised in remote regions on a mass scale:

"[i]n carrying out the division [of USLON] into [territorial] Sections, economic considerations were given priority (i.e. the concentration of individual industrial branch functions) but at the same time, it was impossible not to consider the special conditions of work of USLON and geographical peculiarities."65

A. P. Nogtev envisaged that in the USLON centre the new branch structure would preclude further conflicts between the camp's economic and administrative leadership. The plan is clearly based on the party's 1929 organisational reforms, which had been designed to increase the effectiveness of its interventions in the civil economy during the upheaval of the First Five-Year Plan. A. P. Nogtev now sought to promote these administrative structures and productive objectives as the core principles of the camp's purpose:

62. Ibid., 1. 80.

63. RGASPI, f. 17, op. 33, d. 437,1.71.

64. Sobranie zakonov i rasporiazhenii raboche-krest'ianskogo pravitel'stva SSSR, 22 (1930): 686.

65. Memorandum of April 1930, signed by USLON Chief A. P. Nogtev, in TsGARK, f. 865, op. 32, d. 1, 11. 2-4, 30-35. 
"The central [USLON] function is carried out by the Planning-Control Department, as the organ which [...] works out the control figures, gives all USLON Departments and Sections directives on compiling industrial-financial plans, analyses plans submitted to it and co-ordinates them with projected perspectival plans, supervises execution of plans, enters required modifications, compiles summary reports and draws corresponding conclusions and directs all statistical work carried out in USLON and its Sections."66

In the territorial sections, the new branch sub-structure, dually subordinated to central branch departments and the unified territorial economic-administrative leadership, was intended to promote more autonomous and focussed economic management. Formerly, A. P. Nogtev stated, central departments had

"overcentralised the work of the subordinate periphery and frequently, not having the opportunity sufficiently to learn the needs of the periphery, had turned their own leadership into petty tutelage (melochnuiu opeku), tying the hands and feet of the latter." 67

Because of this, the periphery had endured heavy responsibility without enjoying any independent rights and had become "a blind executive of the directives of the Centre." Under the new plan, territorial sections would operate on their own balance sheets, in accordance - noted A. P. Nogtev - with the resolutions of the Sixteenth Party Conference and the TsK.

According to its author, this reform would enable the camp to triple both its working population (to over 50,000) and its production plan during the subsequent year. To complement these organisational measures, during 1929 and early 1930 a new system of production incentives for the prisoners was introduced, and discipline was strengthened among the guards and camp officials. At this same time, a former prisoner later testified:

"Beatings stopped, as did overtime work [...] prisoners were grouped into various categories according to their physical fitness and given a certain norm of work to complete. If not completed, his bread ration was simply reduced in proportion to the amount done, which automatically forced prisoners to exert themselves since otherwise they were likely to starve." ${ }^{6}$

66. Ibid., 11. 2-4.

67. Ibid.

68. Interview with SLON escapee Reverand Deinas, United States Consulate, Kaunas, Lithuania, 31 October 1933, in US State Department, Records relating to internal Soviet affairs, 1930-1939 (T1429), 861.5017 - Living Conditions/726. Solzhenitsyn, on anecdotal evidence, has attributed the inspiration for this reform of working practices to N. A. Frenkel', a prisoner in SLON since 1927, who allegedly was flown to Moscow in 1929 for an interview with Stalin and high OGPU officials in which he outlined his vision for the expansion and efficient utilisation of forced labour, see Alexander Solzhenitsyn, The Gulag archipelago, 1918-1956, op. cit.: 73-75. This account of Frenkel"s role is corroborated, though with modifications, by several survivor memoirs (although there is a danger of circularity, since Solzhenitsyn might have used these in his investigations). See, for example, Ivan Chukhin's interview with S. L. Moiseev and note on L. M. Khoruzhik, who recalled an USLON official using the term "frenkelevizatsiia", in Kanaloarmeitsy, op. cit.: 30-32; and also Chapter 7, "Frenkel', frenkelizatsiia i pridurki,' in M. Rozanov, Solovetskii kontslager' v monastyre..., op. cit.: 174-191. 
As A. P. Nogtev's plan was implemented, the population of SLON grew from 21,900 in $1928 / 1929$ to 65,000 in $1929 / 1930$ and 71,800 at the start of 1931 (see Figure 1), largely as a result of the OGPU's own brutal campaigns against the kulaks throughout the Soviet Union, as well as the assault on industrial specialists and entrepreneurs, many of whom found themselves on the main island archipelago. ${ }^{69}$ Alongside its demographic expansion, the camp experienced a continuing rapid growth in output that seemed fully to vindicate A. P. Nogtev's confidence in the new system. By 1931, as well as timber felling and sawing and road and railway construction work on the mainland, prisoners were involved in fishing, agriculture, brick-making and various manufacturing activities, such as the production of leather goods. In 1930, the official Solovetskii camp journal boasted that whereas in 1926 USLON had fulfilled orders for Zhelles and Karelles worth 63,000 rubles, by 1929 the value of these operations had grown to 2,355,000 rubles; similarly, USLON's participation in road construction had grown from 105,000 rubles in 1926 to six million rubles in $1930 .^{70}$ The publication, naturally, omitted to account for the human costs of this expansion: according to a leading Russian historian of the camps, the mortality rate in SLON in 1931 was $6.2 \%,{ }^{71}$ which would imply a total number of nearly 4,500 deaths during that year. ${ }^{72}$ Although the establishment of Belomorstroi later in 1931 meant that A. P. Nogtev's plan for USLON was never fully realised, his project for a giant regional camp complex would be the model for the future BBK and for the organisation and expansion of Gulag forced labour throughout the Soviet Union in the 1930s.

\subsection{Karelian relations with USLON, 1930-1931}

An USLON party representative, D. V. Uspenskii, articulated the OGPU's new commitment to complex regional development at the Tenth Conference of the Karelian Party Organisation in May 1930. The SLON prison workforce, he declared, must be used more widely in felling, road construction, fishing, and agriculture in order that Karelia could achieve regional self-sufficiency. The USLON official had chosen his words artfully: Karelian autarky, of course, had long been the holy grail of E. Gylling's republican leadership, although since the late 1920 s it had become an increasingly fantastical aspiration. D. V. Uspenskii promised that henceforth USLON would direct all its resources towards the

69. Details of the camps' population growth from M. B. Smirnov, ed., Sistema ispravitel'notrudovykh lagerei $v$ SSSR..., op. cit.: 395.

70. It is unclear whether these figures take ruble inflation into consideration. Solovetskie Ostrova, 2-3 (1930): 56-57, cited in A. Solzhenitsyn, The Gulag archipelago, op. cit.: 51.

71. Zemskov in V. B. Zhiromskaia, ed., Naselenie Rossii v XX veke. Istoricheskie ocherki. Tom 1. 1900-1939 (Moscow: Rosspen, 2000): 320. Note, however, that the same source gives a figure of 1,438 death in the Solovetskii camp for 1931, ibid.: 319 .

72. This is born out by the memoir evidence, see for example, David J. Dallin, Boris I. Nicolaevsky, Forced labor in Soviet Russia (New York: Octagon Books, 1974): 188-190. 
Figure 1. Population of the Karelian GULAG

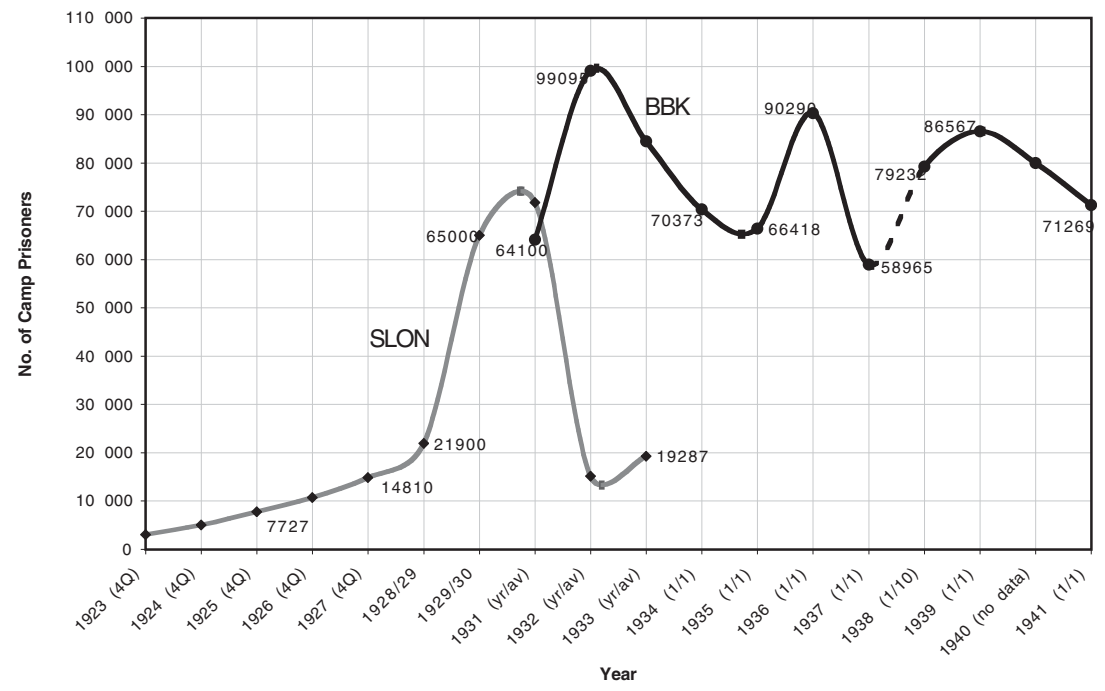

Source: M. B. Smirnov, ed., Sistema ispravitel'no-trudovykh lagerei v SSSR, 1923-1960. Spravochnik (Moscow: Zven'ia, 1998): 162-164, 394-397.

development of Karelia. He also declared candidly that the OGPU's economic potential was in direct proportion to its repressive efficiency:

"We have grandiose possibilities to use those scrap materials (util'syrs'e), that flotsam of the October storm (otbrosov oktiabr'skogo shkvala), those shards of the social structure (oskolkov sotsial'noi stroiki) which come under our authority in greater and greater numbers the more successfully the struggle progresses for the definitive extirpation of the remnants of capitalism." 73

The conference's immediate priority, however, was to ensure an improvement in relations between USLON and Karelia's raion party organisations, among whom, he continued ominously, there had been recent mutterings that "USLON was a class enemy, that it slows down party development, that it spreads dissolution." This was untrue, he responded. Firstly, the Karelians should not confuse the prisoners with their Chekist masters. Secondly, there was no need to panic about the prisoners, since they "are wax in our hands and we remould them in our own way." This, he concluded, was USLON's "creative work," leaving the audience to imagine the forms and methods of Chekist "creativity." 74

73. Dated 28 May 1930, Stenogram, in RGASPI, f. 17, op. 21, d. 1910, 11. 41-50.

74. Ibid. 
Less than a month later, on 18 June 1930, the Karelian Obkom Secretariat passed a resolution designed to harness the OGPU's new commitment to regional development. The resolution 'On new tasks of OGPU camps of special designation in colonisation activity,' based on a report by the new head of USLON A. A. Ivanchenko (who had replaced A. P. Nogtev on 19 May), declared:

" 1 . In connection with the shortage of workforce in the Karelian ASSR, consider it necessary to use USLON workforce in the economic development of Karelia by means of concluding contracts between USLON and Karelian economic organisations on a long-term basis; at the same time to provide USLON with its own economic base for the development of its industrial-economic enterprises.

2 . In principle agree to colonisation of specific territories by groups of USLON prisoners, having made provisions for the political aspects of the question, and in agreement with Karelian governmental plans.

3. With regard to the Karelian ASSR's border position, consider that the population in USLON camps in Karelia is already at a maximum (predel'noe) and must not be increased." 75

In accordance with this decision, a few weeks later USLON submitted a proposal to construct a large paper and pulp enterprise in Pon'gomskii, in the north of Kem' raion, and for this purpose asked the Karelian authorities to transfer this district to its jurisdiction for "long-term autonomous use." At the same time, the Solovetskii authorities protested that Karelles had included USLON's felling programme in the civilian timber plan for this district. The camp authorities, however committed they were to regional development, were determined to assert both territorial and operational independence from the Karelian organisations. ${ }^{76}$

Cooperation between the Solovetskii camp administration and the civil authorities was further hampered by persisting conflicts over costs. In May 1930, Karelles protested to the new Obkom First Secretary Kustaa Rovio that USLON had demanded an extortionate seven rubles and six kopecks per cubic metre for timber cut and transported from the Kem' Lespromkhoz (timber-industrial enterprise, LPKh), when the standard rate was slightly over three rubles. After negotiations, the Chekists accepted a rate of six rubles and 36 kopecks, which Karelles was compelled to pay. The civil organisation, however, could not stretch to the sum USLON insisted on charging for timber floating. In anger and desperation, Karelles requested that the TsK should direct USLON to participate in the regional economic plan by providing labour at the same rates as set for civil enterprises. If USLON refused, the timber agency threatened vainly, Karelia would in future refuse to accept its workforce. ${ }^{77}$ On the same day as Karelles protested via the party line, E. Gylling wrote to the regional representative of the State Timber Export Trust (Leseksport) and to the People's Commissar of the Workers' and

75. Karelian Obkom Secretariat, 18 June 1930, GAOPDF RK, f. 2, op. 2, d. 434,1. 100.

76. Letter from USLON Timber Felling Section to Karelles, dated 12 August 1930, in GAOPDF RK, f. 3, op. 2, d. 85-447,1. 29.

77. GAOPDF RK, f. 3, op. 2, d. 85-447,1. 25. 
Peasants' Inspectorate (Narodnyi Komissariat Raboche-Krest'ianskoi Inspektsii, NKRKI) G. K. Ordzhonikidze, requesting they intervene to "rectify USLON's incorrect attitude" in view of the fact that "Karelian organisations are not capable of influencing USLON on this issue." 78

There were also persisting tensions between raion soviet and party authorities and the local camp administrations. In July 1930, the Secretariat of the Karelian Obkom passed another resolution calling for the TsK to establish an USLON party organisation subordinated to the Obkom. In the meantime, the Karelian raikomy should exercise leadership over USLON party cells located on the mainland for internal party matters, the "everyday economic activity of the camps," and education and propaganda among the free workforce. They would also be responsible for ensuring that local populations were not ideologically contaminated by their contact with prisoners. Local party officials should not, however, interfere in the OGPU's operative work, the resolution concluded confidently, as if its other clauses stood any chance of acceptance by the camp administrators. ${ }^{79}$ In reality, raion officials felt impotent in the face of Chekist arrogance and intimidated by the presence of large prisoner populations in their localities. In August 1930, for example, the Medvezh'egorsk raikom requested a delivery of 250 revolvers to enable local party and soviet workers to protect themselves. Their report to the Obkom on "the disgraceful conduct of USLON prisoners" stated that prisoners were roaming freely throughout the district, wreaking havoc and terrifying the local population to such an extent that citizens were too frightened even to collect berries and mushrooms in the forest (in Karelia in 1930, these foods would have been staple sources of nutrition for the malnourished peasantry). The report demanded that USLON increase the number of guards and curtail the prisoners' "freedom" (sic). What caused the local officials most anxiety, however, were unconfirmed rumours that huge numbers of prisoners were about to arrive to start construction of a canal on their territory. ${ }^{80}$

\section{The Belomor Canal, 1931-1933}

English explorers in the 1560s were the first to propose constructing an artificial canal connecting the White Sea to Lake Onega, with a view to opening up the Muscovite interior to the northern trade routes. ${ }^{81}$ The implementation of this scheme, however, awaited, in the words of the official OGPU history of the

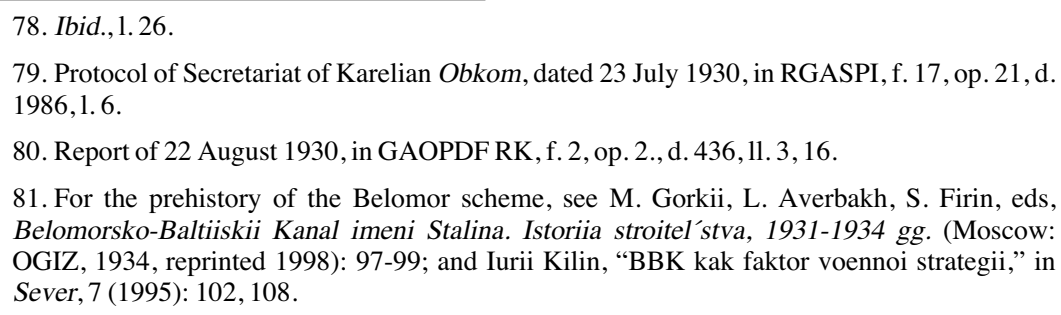
Belomorsko-Baltiiskii Kanal imeni Stalina. Istoriia stroitel'stva, 1931-1934 gg. (Moscow: OGIZ, 1934, reprinted 1998): 97-99; and Iurii Kilin, "BBK kak faktor voennoi strategii," in Sever, 7 (1995): 102, 108. 
construction, "the unified will of the party and the armed theory of Lenin and Stalin." 82 Equally necessary preconditions were the utopian spatial visions of Bolshevik planning in the late 1920s; the need to create demand to meet an explosion in the supply of forced labour resulting from collectivisation; and the ambition of the OGPU to carry out a prestigious project to prove the economic efficiency and political value of using its own special methods to open up, colonise and develop remote regions.

The Soviet Navy reviewed pre-revolutionary plans to build a canal immediately after the Revolution, but it was not until the late 1920s that the military and political leadership finally agreed to its construction. Their immediate motivation in making this decision was strategic: building the canal would enable the Baltic fleet to be transferred to the ice-free port of Murmansk, constructed in 1916, from where its ships could gain access westwards to the Atlantic, and via the newly opened Great Northern Sea Route also to the Far East, where the Japanese threat to Soviet territory became the regime's foremost international concern. The other purpose of the canal, of course, was economic. It would enable the Soviet economy to draw on new sources of wealth from the Far North, in particular timber, coal, metals and minerals. Once linked by the Belomor Canal via the Mariinksii water route, which was already undergoing reconstruction at this time, to the Russian interior and via the Svir-Ladoga-Neva canals to Leningrad, the Northern Sea Route could also provide a cheap transport route between Russia's industrial centres and the Far East, obviating the need to circumnavigate Scandinavia, and easing congestion on the railways. ${ }^{83}$

From the perspective of Karelian and OGPU regional interests, this project also opened up the possibility of developing the autonomous republic as a major industrial centre for processing both timber felled locally by prisoners and raw materials extracted by forced labour in the camps of the Far North and Far East. The OGPU also claimed that the construction of a canal would serve to transmit Soviet civilisation to the frontier. This 'cultural' purpose had two aspects. Firstly, the canal would stimulate economic activity in the North, which in turn would bring the benefits of the Soviet way of life. The following poem by a Belomor prisoner, invoking a panoply of prefigurative synecdoche - factories, cities, chimneys, electric light, reading rooms, club and theatres - exemplifies this Soviet vision of development:

Gde mshistye skaly i vody

Dremali, tam siloi truda

Postroeny budut zavody

I vyrastut tam goroda.

82. M. Gorkii et al., Belomorsko-Baltiiskii Kanal imeni Stalina..., op. cit.: 25.

83. See Narkomput' report on the White Sea - Baltic Waterway (Belomorsko-Baltiiskii Vodnyi Put', BBVP), no date (mid-1930), in GARF, f. 9414, op. 1, d. 1806,11. 1-3, which offers a comprehensive list of perceived advantages, lending important insights also into strategic and foreign policy priorities of the time. 
Vzov'iutsia fabrichnye truby

Pod severnye nebesa,

Chitalen, teatrov i klubov

Ogniami blesnut korpusa. ${ }^{84}$

Secondly, the construction project would serve to rehabilitate 'anti-Soviet' and 'socially alien' elements through purposeful forced labour. Maxim Gorky later wrote that on the "pedagogical experience of the White Sea-Baltic Canal [...] and other colonies of that type, we, literary figures, must understand what fantastic results our system of education with the truth provides and how great the power of this single revolutionary truth is." 85 The canal construction, both by reconfiguring Soviet 'natural' space and by demonstrating the solution of the "greatest scientificpsychological and philosophical problem of the remaking of people" 86 could be appropriated through propaganda to vindicate Marxist-Leninist ideology and 'reforge' society accordingly both on the periphery and in the centre. In the OGPU's published history of the construction, the association between 'natural' space, human intervention and the transformation of human 'nature' is made explicit: two chapters in sequence are introduced by full-page illustrations captioned, firstly: "The canal passed here - a new nature has been created" and, secondly: "By changing nature, man changes himself." 87 The OGPU would be the instrument of this revolutionary human engineering. In the words of a contemporary,

"it is no accident, but deeply symptomatic, that precisely the keenest weapon of the dictatorship of the proletariat, the 'guarding sword' of the proletariat - the GPU - is not only the weapon of repression, but... the organ of the education and re-education of people." 88

To what extent the camp officials themselves believed in this 'higher' justification of their activities remains an open question. As we have already heard, USLON officials too spoke - with ominous ambiguity - of their "creative work."

84. "Where mossy cliffs and waters/Slumbered, there by the strength of labour/Factories will be built/And towns will grow./Factory chimneys will rise up/Under the northern skies./ Buldings will shine with the lights/Of reading rooms, theatres and clubs." Poem by kanaloarmeets Medvedkov, cited in Petr Karelin, "The first anniversary of the BelomorBaltiiskii Combine," Karelo-Murmanksii Krai, 7-8 (1934): 1. For more Belomorstroi poetry and songs, see for example, M. Gorkii et al., Belomorsko-Baltiiskii Kanal imeni Stalina..., op. cit.: 475-478; I. Chukhin, Kanaloarmeitsy, op. cit.: 109, 111, 130-131; Cynthia A. Ruder, Making history for Stalin. The story of the Belomor Canal (Gainesville: University Press of Florida, 1998): 12-13, 138-139, 173-185

85. M. Gorkii, "O kochke i o tochke," in O literature (Moscow: Khudozhestvennaia literatura, 1935): 175, cited in C. A. Ruder, Making history..., op. cit.: 98.

86. Iogann Al'tmann, "Kniga o bol'shoi pobede," Literaturnyi kritik, 6 (1934): 255, in C. A. Ruder, Making history..., op. cit.: 151.

87. The second caption is a quotation from Marx. In M. Gorkii et al., Belomorsko-Baltiiskii Kanal imeni Stalina..., op. cit.: 280, 318.

88. Italics in the original. I. Al'tmann, "Kniga o bol'shoi pobede," art. cit.: 255-256, in C. A. Ruder, Making history..., op. cit.: 151. 
Certainly, there were reading rooms, a theatre and clubs for Belomorstroi workers, and much of the propaganda of the construction project projected narratives of prisoners finding new meaning in their labour as a result of cultural enlightenment. Even if the administrators were sincere about this aspect of their work, however, it was clearly at most incidental to their priorities, which were to build the passage in the quickest time and at the lowest capital cost, regardless of the suffering involved.

\subsection{Belomorstroi: The construction of the canal}

On 5 May 1930, the Politbiuro passed a resolution entitled "On the canal" which set out the main objectives of the construction project: the southern section was to be started in 1931, and to be finished it within two years, to a depth to permit the passage of ships of 18-foot displacement, and to a cost of below sixty million rubles; the northern section (between Lake Onega and the White Sea through central Karelia) was to be explored by Narkomput', the military authorities and the OGPU, and costs were to be minimised by taking into account the possible use of prison labour. ${ }^{89}$ On 15 May 1930, a Special Committee for Belomorstroi was established under the chairmanship of the People's Commissar of Transport Ia. E. Rudzutak, including among its members G. G. Iagoda from the OGPU and representatives from the military..$^{90}$ On 26 May, Narkomput' set up an Administration for the Construction of the Belomorsko-Baltiiskii Water Route (BBVP) under its own Deputy Commissar G. I. Blagonravov. ${ }^{91}$ This became the operational administration of Belomorstroi. On the last day of the month, the Special Committee agreed that the southern section of the canal should accommodate vessels of 28 -foot displacement and that the OGPU should provide the construction workforce..$^{92}$ However, a resolution of the STO of 3 June confirmed the earlier Politbiuro resolution, which had envisaged a depth of 18 feet. ${ }^{93}$

In February the following year, the Politbiuro agreed that the OGPU would be responsible for the canal construction, replacing Rudzutak as Chaiman of the Special Committee for Belomorstroi with G. G. Iagoda, and confirmed a final construction plan which, amongst other things, further reduced the maximum depth

89. Politbiuro Protocol 125, 5 May 1930, in RGASPI, f. 17, op. 3, d. 784, 1. 2. This resolution has been published in Lars T. Lih, Oleg V. Naumov, Oleg V. Khlevniuk, eds, Stalin's letters to Molotov (New Haven and London: Yale University Press, 1995): 212, n. 1.

90. Protocol 1 of Special Committee, in GARF, f. 9414, op. 1, d. 1806, 1. 5.

91. Instruction of Narkomput', dated 26 May 1930, in GARF, f. 9414, op. 1, d. 1806,1. 10.

92. Protocol 2 of Special Committee, in GARF, f. 9414, op. 1, d. 1806, 1. 8.

93. STO resolution "On the construction of the Belomorsko-Baltiiskii Canal," 3 June 1930, in GARF, f. 9414, op. 1, d. 1806, 1. 4. The Politbiuro confirmed its decree of 5 May 1930 with a further resolution "On the Belomorsko-Baltiiskii Canal," dated 20 June 1930, Protocol 129, p. 13, in RGASPI, f. 17, op. 3, d. 788,1.3.

Lars T. Lih, Oleg V. Naumov, Oleg V. Khlevniuk, eds, Stalin's letters to Molotov, op. cit.: 212, n. 1 
of the canal to twelve feet, scarcely sufficient to permit the passage of most naval vessels. This revision, however, enabled the agency to guarantee it would spend no more than sixty to seventy million rubles on the construction, including "not one kopeck of hard currency," and would finish the project by the opening of navigation in 1933.94 In April 1931, OGPU personnel took over most of the top posts of Belomorstroi, frustrated with the interference of their Narkomput' civilian counterparts. ${ }^{95}$ On 16 November 1931, full responsibility for the northern section was transferred from Narkomput' to the OGPU. On the same day, the OGPU established the Belomorsko-Baltiiskii ITL to replace the Solovetskii ITL, since most of the prisoners in Karelia had by now been transferred from the islands to the mainland. ${ }^{96}$ These moves confirmed and strengthened the OGPU's role as a powerful economic organisation in its own right, and laid the basis for its future expansion.

Alongside the OGPU, the Karelian leadership also energetically promoted the canal project while striving without great success to gain a say in development decisions. ${ }^{97}$ At the end of August, E. Gylling secured a seat on the Special Committee. The protocols of the Committee, however, indicate that he rarely attended its meetings in Moscow. Indeed, in April 1931, he wrote to Rudzutak (in the latter's role as Deputy Chairman of the Sovnarkom) complaining that although he was a member of the Special Committee on Belomorstroi, he had as yet received no information from the OGPU concerning the projected route of the canal. The Administration of Solovetskii Camp (USLAG) ${ }^{98}$ had even started felling trees across a swathe of central Karelia due to be flooded, ${ }^{99}$ without giving the republican government notice to make arrangements for evacuating nearly 4,000 local inhabitants, ${ }^{100}$ for integrating this intensive activity into regional timber plans or for

94. Politbiuro meeting of 10 February 1931, see Protocol 26, dated 15 October, in RGASPI, f. 17 , op. 3 , d. $813,1.11$.

95. GARF, f. 9414, op. 1, d. 1806, 11. 24-5. Although Blagonravov was replaced by senior OGPU official G. E. Prokof'ev as Head of Belomorstroi (until August 1931, when Prokof'ev was replaced by L. I. Kogan), the chairmanship of the Special Committee in fact alternated between G. G. Iagoda and N. M. Ianson, head of the new People's Commissar of Water Transport (Narkomvod), established on 30 January 1931, which remained responsible for the construction of a port at Soroka, at the mouth of the canal into the White Sea.

96. M. B. Smirnov, ed., Sistema ispravitel'no-trudovykh lagerei v SSSR..., op. cit.: 162, 394, 396. The Solovetskii ITL was not definitively dissolved until 1 November 1933.

97. In this connection, it is interesting to note that E. Gylling later refused to co-operate with the OGPU writers' collective composing a history of the construction, believing - doubtless correctly - that it would only represent the OGPU's point of view, see Letter of Engineer Lunev to the Chief Editor of the BBVP edition, dated October 1932, in TsGARK, f. 520, op. 2, d. $3 / 18,11.115$.

98. For the change of name from USLON to USLAG, probably at the establishment of ULAG OGPU in May 1930, see M. B. Smirnov, Sistema ispravitel'no-trudovykh lagerei v SSSR, op. cit.: 395 , n. 1. For a brief period, the camp was subordinated to the Karelian GPU, at which time it was known as Solovetskie i Karelo-Murmanskie lageria OGPU (SKM ITL).

99. In fact, the felling was carried out by Belbaltlag in the Murmansk railway zone under contract to Narkomput', for which it charged three million rubles, see GARF, f. 5446, op. 13, d. 519. 
drawing up revised plans for local industrial development. Rudzutak forwarded this note to the Co-chairman of the Special Committee, People's Commissar for Water Transport (Narkomvod) N. M. Ianson, who sent it on to G. G. Iagoda, with a query scribbled in blue pencil across the top of the page: "Is E. Gylling really a member of the Committee? No one told me! If so, we should invite him to future meetings of the Committee." G. G. Iagoda tersely confirmed that E. Gylling was a member, and a month later sent the Karelian government a report on the canal, with a note that the republican People's Commissariat of Agriculture should liaise with the Belomorstroi administration (located in Moscow, conveniently just behind the Lubianka) on questions of evacuating local inhabitants from villages marked for flooding. ${ }^{101}$

From this point, E. Gylling took a more active role. In December 1931, he travelled to Moscow to argue that the centre should subsidise the estimated six million rubles cost to Karelia of evacuations from the flooding zone. He was not present, however, when in April 1932 the military protested at projected work on the Svir section of the canal (on the southern border of Karelia), which would reduce the canal's depth to a mere six feet. This, declared the RevolutionaryMilitary Council (Revvoensovet) representative, would "completely negate the purpose of work finished between Onega and the White Sea." 102 The fact that the canal would be useless for military purposes did nothing to discourage the OGPU, however, whose only concerns now were to finish the project cheaply, by the promised deadline and with appropriate publicity. For this purpose, as soon as navigation opened in spring 1931 they transferred most of the remaining Solovetskii workforce onto the mainland, as the Medvezh'egorsk raion party officials had earlier feared. ${ }^{103}$

In a speech to the Communist Academy and the Institute of Soviet Construction in October 1933, the chief of Belbaltlag S. Firin stated that 140,000 prisoners had been employed on the canal project. ${ }^{104}$ Historians since have offered widely differing estimates of the numbers of prisoners engaged on Belomorstroi (between 100,000 and 500,000), and of the total number of deaths on the construction project

100. GARF, f. 5446 , op. 15 , d. 1404.

101. GARF, f. 9414, op. 1, d. 1805, 11. 81-84.

102. Special opinion of R. A. Muklevich, member of the Revvoensovet, attached to Protocol 7 of Special Committee, dated 26 April 1932, in GARF, f. 9414, op. 1, d. 1806, 1. 44. For more detail on this controversy and its consequences, see Iurii Kilin, "BBK kak faktor voennoi strategii," in Sever, 7 (1995): 109-112.

103. Likhachev was transferred at this time from Solovetskii Island to a village near Medvezh'ia Gora, see D. S. Likhachev, Reflections on the Russian soul..., op. cit.: 178-187.

104. Published in Krasnaia Kareliia, 11 March 1934, and in Vestnik Kommunisticheskoi Akademii, 5 (1933): 90-91 (I am very grateful to Bob Davies for alerting me to the latter source). Note that in this speech, Firin also stated that only 37 professional Chekists were employed on the construction site, an improbable figure which might cast doubt on the credibility of his testimony. 
(between 50,000 and 250,000). ${ }^{105}$ Archival sources now permit us to calculate more accurate figures. According to OGPU estimates of 2 July 1931, Belomorstroi would require thirty million working days to complete the canal by the end of 1932 (over the projected 18 months, this meant an average 55,000 workers on the construction at any time). In summer 1931 , an average 65,000 prisoners were active on the construction sites each day (plus about 13,000 prisoners in subsidiary functions). However, the report complained that this workforce was poorly qualified, equipped only with manual tools, and yielded low productivity. Optimally the OGPU required a daily workforce of 100,000 , but as there was insufficient accommodation and too few tools for this number, it agreed to make do with 75,000, although these - noted the memorandum - would have to be worked very intensively. To raise numbers to and maintain them at this level, the report requested the central Gulag administration to supply an extra 15,000 prisoners immediately, and up to 43,000 by the end of July (these figures give an impression of the expected rate of labour turnover). Forward projections for 1932 considered 75,000 workers to be the minimum required, with an optimal number of 90,000 , to enable the project to be completed by deadline. ${ }^{106}$ In fact, a May 1932 report by N. M. Ianson stated that the workforce already totalled 100,000 and would be raised to 125,000 during July and August (although there were only barracks for 60,000 , and the remainder was accommodated in tents). ${ }^{107}$

One other document offers a glimpse of the Belomorstroi labour force. In 1936, the editor of an anthology of articles on Karelia, Vsia Kareliia, submitted a draft chapter on the Belomor Canal to D. V. Uspenskii, now head of the BBK, for approval to publish. The draft was returned with the acerbic comment: "I consider that the publication of this article is senseless if not harmful." The NKVD official had been upset by several statements in the paper. First of all, the author had written in consecutive phrases that the canal was built by "the hands of over 100,000 prisoners in OGPU camps" in harsh northern conditions and that "against an estimated cost of 400 million rubles, a total of only about 100 million had been spent." "This," wrote D. V. Uspenskii, "is undoubtedly a reference to the fact that

105. These ranges adapted from R. Stettner's survey of secondary sources, Archipel GULag, op. cit:: 231, 234. D. J. Dallin and B. I. Nicolaevsky state that the workforce "reached almost 300,000 at its peak," in Forced labor in Soviet Russia, op. cit.: 212-213; C. A. Ruder states that during 1931-1933 over 126,000 prisoners worked on the canal, in Making history..., op. cit:: 25, after I. Chukhin, Kanaloarmeitsy, op. cit.: 209, A. Solzhenitsyn reports that at least 100,000 died during the winter of 1931-1932, and up to 250,000 in total, in The Gulag archipelago..., op. cit.: 90-91, 94. Tuominen reports an average workforce of 60,000 and estimates deaths between 60-200,000, Arvo Tuominen, in The bells of the Kremlin. An experience in communism (Hanover and London: University Press of New England, 1983): 67, 74. M. B Smirnov gives the following archival figures for the average annual Belbaltlag population: 1931-64,000; 1932-99,095; 1933-84,504, in Sistema ispravitel'no-trudovykh lagerei v SSSR..., op. cit.: 162 . See also footnote 112 .

106. "Explanatory notes to operative estimates, July-December 1931," dated 2 July 1931, in GARF,f. 9414 , op. 1, d. 1805, 11. 102ob-103.

107. Report on State of Construction of BBVP, dated 1 May 1932, in GARF, f. 9414, op. 1, d. $1806,1.45-55$. 
we drove the prisoners as hard as was possible (iz zaklyuchennykh vyzhali vse)." The author had also included a discussion of the canal's strategic significance for the defence of Leningrad - such considerations were not supposed to be made public (especially, we suspect, as the completed canal was strategically useless). Two pages later, the author consummated his error by noting that the completion of Belomorstroi had in fact required ninety million working days. ${ }^{108}$ From this disclosure, we can calculate that over the 21-month construction period the average number of prisoners working on the site was approximately 143,000. This corroborates the total given by S. Firin in 1933, but it does not allow for turnover of workforce, which we surmise was largely accounted for by injury and mortality.

According to figures published by the Russian historian V. N. Zemskov, annual mortality in the Belbaltlag in 1933 amounted to $10 \% .{ }^{109}$ This would imply (given an average population of 143,000 ) that there were 25,025 deaths on the canal over the 21-month period of construction. This estimate is considerably greater than the separate figures V. N. Zemskov offers for total deaths in the Belbaltlag in 19321933 (10,936), but almost identical to the total deaths in Belbaltlag, Solovetskii and Svirlag (which constructed the southern section of the canal) during the three years 1931-1933 (25,019). ${ }^{110}$ If this calculation seems far lower than previous estimates of mortality on the canal, it should be remembered that this accounts only for immediate deaths; we can assume that numbers who died subsequently as a result of having been invalided or debilitated by canal work exceed this amount by a high factor. Even assuming a rate of turnover due to injury at $2 \%$ (only a fifth of the rate of mortality), the total number of prisoners employed on Belomorstroi would have approached $175,000.111$ This was equivalent to over half of the average Soviet prison camp population in the years 1931-1933.112

As the OGPU indicated, the quality of the workforce presented a problem, but this was a challenge that Chekist 'creativity' could overcome. On 29 November 1930, the deputy head of the OGPU Transport Department V. A. Kishkin and the deputy head of the Administration of Camps (ULAG) Ia. D. Rapoport (future chief

108. Letter from D. V. Uspenskii to Karelian First Obkom Secretary P. A. Irklis, dated 24 February 1936, in GAOPDF RK, f. 3, op. 4, d. 165/159,1.36; see also the offending article by I. V. Pervozvantsev, "Belomorsko-Baltiiskii Kombinat," 11. 37-66.

109. In V. B. Zhiromskaia, ed., Naselenie Rossii v XX veke..., op. cit.: 320 . He does not give figures for 1931 or 1932, and it should be noted that the 1933 death rate was likely to have been particularly high owing to the famine. Note also that in 1933 mortality in the Solovetskii camp, dissolved in that year, amounted to $18.1 \%$, in ibid.

110. V. B. Zhiromskaia, ed., Naselenie Rossii v XX veke..., op. cit.: 119.

111. There are no available figures for prisoners incapacitated by injury. A recent Gulag history states that on 1 January 1931, of the total Gulag population $1.8 \%$ were "non-working" (no source indicated), M. B. Smirnov, S. P. Sigachev, D. V. Skapov, "Il sistema dei luoghi di reclusione in Unione Sovietica, 1929-1960," in M. Flores and F. Gori, eds, GULag. Il sistema dei lager in URSS, op. cit.: 61

112. The following figures are given by V. N. Zemskov for total Soviet special camp populations, with mortality (in brackets): 1931-240,350 (7,283); 1932 - 301,500 (13,267); 1933-422,304 (67,297), in V. N. Zemskov, "GULAG (istoriko-sotsiologicheskii aspekt)," Sotsiologicheskie issledovaniia, 6 (1991): 14-15. 
of the BBK, 1933-1935) wrote to G. G. Iagoda complaining that the general (valovaia) labour force under ULAG's authority could not carry out technically more demanding tasks in the southern (Svir) sector of the Belomor Canal. The solution, they proposed, would be for the Transport Department to send ULAG a number of recently arrested wreckers, including two major experts in the deepening of river beds, eight to ten other engineers and ten to fifteen middle-ranking technicians. It is likely that they are referring to specialists arrested in connection with the Industrial Party trial, which had opened in Moscow only four days earlier. ${ }^{113}$ Although there were only eight defendants at the trial, they were charged with recruiting over two thousand other specialists as saboteurs, including - as luck would have it - the entire Central Asian Hydrology Department. ${ }^{114}$ These captive experts, Rapoport and Kishkin proposed, would be accommodated in a special camp to be opened near Leningrad. The Belomorstroi Special Construction Bureau (Osoboe Konstruktorskoe Biuro, OKB) - perhaps the first 'official' camp sharashka ${ }^{15}$ - was in fact established in Moscow and moved to Medvezh' ia Gora in November 1931 (this office evolved into the BBK's research and planning bureau, which was located in Leningrad). The letter concluded with a promise which offers some insight into the priorities and working practices of the OGPU at this time: "Additionally, in the course of the investigation, several other suitable persons will be arrested, as planned (budet doarestovano)." 116 Indeed, the Industrial Party case was accompanied by a renewed and intensified wave of arrests of engineers and specialists accused of wrecking, many of whom found themselves working in the Belomorstroi OKB. ${ }^{117}$ The relationship between cause and effect remains more fully to be explored.

Thanks to its cost-cutting revision of the canal's blueprints and its ruthless exploitation of the workforce, the OGPU completed the canal's northern section, linking the White Sea and Lake Onega, in June 1933, only one month over its deadline and within the revised project budget. In July 1933, Stalin directed G. G. Iagoda to present proposals on awards and amnesties to be given to officials and prisoners on completion of the canal. ${ }^{118}$ In early August, the canal was

113. For the Industrial Party case, and its consequences for Soviet professionals, see Roy Medvedev, Let history judge. The origins and consequences of Stalinism, revised ed. (Oxford: Oxford University Press, 1989): 263-289; R. W. Davies, The Soviet economy in turmoil, 19291930 (Basingstoke: Macmillan, 1989): 406-411.

114. According to Michel Heller, Stacheldraht der Revolution. Die Welt der Konzentratsionslager in der sowjetischen Literatur (Stuttgart: Seewald, 1975): 130, 134, 137, cited in R. Stettner, Archipel GULag, op. cit.: 231, n. 223.

115. On sharashki, see Zhak [Jacques] Rossi, Spravochnik po GULAGu (Moscow: Prosvet, 1991): 452-453

116. It is not clear whether they already had specific people in mind for arrest, or just the functions that needed fulfilling, GARF, f. 9414, op. 1, d. 1805, 1. 66.

117. For pen portraits of Industrial Party 'wreckers' employed in Belomorstroi, see Chapter 3 of M. Gorkii et al., Belomorsko-Baltiiskii Kanal imeni Stalina..., op. cit.: especially 77-97.

118. Stalin also warned newspaper editors to ensure they published no "boastful comparisons" with the Suez and Panama canals. Politbiuro Protocol 140, dated 1 July 1933, p. 3, in RGASPI, f. 17 , op. 3 , d. $925,1.2$ 
officially opened and a Politbiuro commission headed by Kuibyshev agreed on 15 August to commence the construction of an industrial complex, the BBK, on territory adjoining the canal. ${ }^{119}$

The Sovnarkom SSSR decree of 17 August which confirmed the creation of the BBK and - to E. Gylling's inevitable disappointment ${ }^{120}-$ placed it under OGPU authority, gave the new institution the task of developing the economy of the recently constructed canal and its adjacent forests. ${ }^{221}$ This prompted politicians and planners, in Karelia, in Leningrad and in Union and Russian institutions in the centre, fundamentally to reconsider their visions of regional development. This also brought about an increasing coincidence of interests between the Karelian civil authorities and the OGPU-NKVD. In a subsequent paper, I look at the development of the Combine in the period 1933-1939, considering in particular its relations with the Karelian and Leningrad authorities; its visions of spatial development; its economic planning and performance; the camp population, living conditions and mortality; discipline, the administration of camp 'justice' and the agencies, procedures and statistics of camp repressions. ${ }^{122}$

\section{Conclusion}

The 'special' camp system originated as a means of isolating those perceived to be hostile to the Soviet system, both political adversaries and recalcitrant criminals, in remote sites where they could neither attack nor contaminate the centre. Established in 1923, the Solovetskii camp evolved in the course of the decade into a powerful regional economic organisation. Each year, the OGPU sent more prisoners to Solovetskii and expanded the camp's productive activities with the aim of reducing its annual deficit and reliance on central funding. However, each year the growth in population and the increasingly complex camp economy incurred costs higher than the extra revenue they generated, and the camp continued to depend on central subsidies to underwrite its further expansion. The Karelian government strongly opposed the establishment of the camp and strove to resist its progressive encroachment onto the mainland, but it could do nothing to prevent other economic organisations, in particular the Murmansk railway, from exploiting

119. In the Politbiuro meeting of 15 August, it was agreed to consider deepening and widening the canal to permit full military usage, RGASPI, f. 17, op. 3, d. 928, 1. 24. This project was superseded by the more feasible and cheaper project of building a second canal, running alongside the first. This, however, was never implemented. See Iu. Kilin, "BBK kak faktor voennoi strategii," art. cit.: 111-112; Id., Kareliia i zimniaia voina. Kareliia v 1920-1941 gg.: diplomatiia, strategiia, ekonomika, politika, unpublished MS, pp. 35-36.

120. With a rare sense of realism, the Karelian Obkom Bureau on 21 June 1933 decided not to petition to take over control of the Belomor Canal and the industrial combine planned for its territory, see Protocol 50, in GAOPDF RK, f. 3, op. 3, d. 12.

121. TsGARK f. 865, op. 36, d. 1,11. 35-36.

122. Nick Baron, "Production and terror: The operation of the Karelian Gulag, 1933-1939," to be published in the next issue of the Cahiers du Monde russe.. 
the supply of camp labour to meet the growing needs of their operations within Karelian territory. At the end of the decade, Karelian organisations also turned to USLON as a means of overcoming the critical regional labour shortage.

As demand grew, so did supply. In 1929, G. G. Iagoda defined colonisation and the economic development of the unpopulated frontiers of Soviet territory as the primary objectives of the camp system. USLON reformed both its administrative structure and organisation of labour with a view to increasing its productive efficiency, and the new system formed the model for other camps established at this time and later. At the same time, the OGPU received huge numbers of new prisoners as a result of its terror campaigns in the Soviet countryside, and deployed these in the newly reformed camp system to further promote its geographic and economic expansion. The Belomor Canal construction was devised as a showcase project to demonstrate the economic advantages of forced labour, as well as its potential to 'reforge' criminals and political enemies into loyal, industrious citizens. This is not to suggest that 're-education' was ever a primary concern of the 'special' camp system, but it played an important subsidiary role in rhetorically justifying the enterprise.

The reality of forced labour, of course, was brutal. Mass killing was never a primary purpose of the 'special' camp system in the period under survey, but arbitrary brutality and 'incidental' death from extreme hardship were defining characteristics of the OGPU's camp regime and organisation of production. Forced labour was also, in the long term, economically counter-productive. The fact that USLON required annual subsidies from the centre to support its economic activities and to underwrite its expansion points to the inefficiency of its prison workforce. More significantly, the fact that the same agency was responsible for conducting arrests and exploiting the labour of prisoners could not fail to induce its planners to assume a potentially open-ended labour supply, and to devise expansionary schemes without due consideration of total costs, including the costs of human labour transferred from the free to the unfree economy, and the costs incurred in undertaking projects which would not offer viable economic returns in the long term, such as the development of the Far North.

In the late 1920s, however, the OGPU persuaded central authorities of the advantages of using prison labour on a mass scale as an efficient means of allocating and utilising human resources during a period of accelerated economic development and (not coincidentally) of expanding repression. The OGPU's interests in promoting Karelian regional development also coincided with the interests of the republican authorities, who by this stage could find no alternative way of recruiting sufficient labour to fulfil their plan targets and acceded to the inevitable further growth of the 'special' camp system within their territory.

During the period under survey in this paper, the OGPU 'special' camp system in Karelia expanded as a semi-autonomous institution, fulfilling the state's security policy, but also defining its own economic role and the direction and shape of its own development in response to both central and regional opportunities. The Karelian camp system established structures, methods and objectives which formed 
a basis for the further expansion of the Gulag throughout the Soviet Union. The sequel paper will trace how, from 1933 onwards, the Stalinist centre increasingly asserted political control and planning discipline over the Karelian Gulag, dismantling the BBK's grand vision of regional development and defining its primary tasks of production and repression.

\section{Department of History \\ The University of Manchester \\ Oxford Road \\ Manchester M13 9PL \\ United Kingdom}

e-mail:npbaron@man.ac.uk 